\title{
Uji Aktivitas Antikolesterol Partisi N-Heksana, Metanol Dan Ekstrak Etanol Kulit Jeruk Nipis (Citrus Aurantiifolia) Secara In Vitro
}

\author{
Iesyi Lutfiyati ${ }^{1}$, Urmatul Waznah ${ }^{2 *}$, S Slamet $^{3}$, W Wirasti $^{4}$ \\ 1,2,3,4 Sarjana Farmasi, Fakultas Ilmu Kesehatan, Universitas Muhammadiyah Pekajangan \\ Pekalongan, Indonesia \\ *email: urmatul.farmasi@gmail.com
}

\begin{abstract}
Cholesterol is an important sterol in human body tissue which belongs to the lipid group but cannot be hydrolyzed. Cholesterol has various uses in the body such as forming steroid hormones in the hormones estrogen and progesterone. However, if cholesterol levels in the blood are too high, it can cause blockage of blood flow which can lead to atherosclerosis. Lime contains secondary metabolites that function to reduce the increase in cholesterol levels in the blood. The purpose of this study was to determine the anticholesterol activity and to determine the $\mathrm{EC}_{50}$ value of partition $\mathrm{n}$-hexane, methanol, ethanol extract of lime peel (Citrus aurantiifolia) in vitro. Analysis of cholesterol activity is known by measuring cholesterol levels in vitro using Lieberman Burchard reagent. The analytical method used UV-Vis spectrophotometry at a wavelength of $665.0 \mathrm{~nm}$ with a series of test sample concentrations of $150 \mu \mathrm{g} / \mathrm{ml} ; 300 \mu \mathrm{g} / \mathrm{ml} ; 450 \mu \mathrm{g} / \mathrm{ml} ; 600 \mu \mathrm{g} / \mathrm{ml}$ and $750 \mu \mathrm{g} / \mathrm{ml}$. The research data shows that the decrease in cholesterol levels is directly proportional to the increase in the concentration in the sample. The $\mathrm{EC}_{50}$ value of the n-hexane partition was $448.76 \mu \mathrm{g} / \mathrm{ml}$; methanol partition as much as $448.98 \mu \mathrm{g} / \mathrm{ml}$ and ethanol extract as much as $450.18 \mu \mathrm{g} / \mathrm{ml}$.
\end{abstract}

Keywords: Anticholesterol; in vitro; lime peel; partition.

\begin{abstract}
Abstrak
Kolesterol merupakan sterol yang penting dalam jaringan tubuh manusia yang termasuk pada golongan lipid tetapi tidak dapat terhidrolisis. Kolesterol memiliki berbagai kegunaan dalam tubuh seperti pembentuk hormon-hormon steroid pada hormon esterogen dan progrsteron. Namun, jika kadar kolesterol dalam darah terlalu tinggi maka dapat menyebabkan penyumbatan aliran darah yang dapat mengakibatkan penyakit Aterosklerosis. Jeruk nipis memiliki kandungan metabolit sekunder yang berfungsi untuk mengurangi kenaikan kadar kolesterol dalam darah. Tujuan pada penelitian ini yaitu mengetahui aktivitas antikolesterol dan mengetahui nilai $\mathrm{EC}_{50}$ dari partisi n-heksana, metanol, ekstrak etanol kulit jeruk nipis (Citrus aurantiifolia) secara in vitro. Analisis aktivitas kolesterol diketahui dengan mengukur kadar kolesterol secara in vitro menggunakan pereaksi Lieberman Burchard. Metode analisis menggunakan spektrofotometri UV-Vis pada panjang gelombang $665,0 \mathrm{~nm}$ dengan seri konsentrasi sampel uji $150 \mu \mathrm{g} / \mathrm{ml} ; 300 \mu \mathrm{g} / \mathrm{ml} ; 450 \mu \mathrm{g} / \mathrm{ml} ; 600 \mu \mathrm{g} / \mathrm{ml} \mathrm{dan} 750$ $\mu \mathrm{g} / \mathrm{ml}$. Data penelitian menunjukkan penurunan kadar kolesterol berbanding lurus dengan peningkatan konsentrasi pada sampel. Nilai EC50 partisi n-heksana sebanyak 448,76 $\mu \mathrm{g} / \mathrm{ml}$; partisi metanol sebanyak 448,98 $\mu \mathrm{g} / \mathrm{ml}$ dan ekstrak etanol sebanyak 450,18 $\mu \mathrm{g} / \mathrm{ml}$.
\end{abstract}

Kata kunci: Antikolesterol; in vitro; kulit jeruk nipis; partisi.

\section{Pendahuluan}

Kolesterol sangat dibutuhkan oleh tubuh dalam pembentukan dinding sel yang berfungsi untuk bahan dasar terbentuknya hormon-hormon steroid dan sumber energi. Jika kadar kolesterol dalam darah tinggi, maka akan memicu adanya penyakit [1]. Sejak dari jaman nenek moyang kita sebagian banyak tumbuhan itu dimanfaatkan 


\section{Prosiding Seminar Nasional Kesehatan Lembaga Penelitian dan Pengabdian Masyarakat Universitas Muhammadiyah Pekajangan Pekalongan}

sebagai obat untuk berbagai penyakit, pengobatan dengan tumbuhan sering disebut sebagai obat herbal. Salah satu tumbuhan herbal yang sering digunakan pada masyarakat Indonesia sebagai pengobatan tradisional adalah jeruk nipis (Citrus aurantiifolia) [12].

Berdasarkan dari hasil penelitian Elon dan Polancos (2015) menyatakan bahwa jeruk nipis dapat menurunkan kadar kolesterol dalam darah, pada terapi jus jeruk nipis dengan atau tidak olahraga maka hasilnya sama dalam menurunkan kadar kolesterol dalam darah. Kandungan pektin (flavonoid pada jeruk nipis) dapat menurunkan kadar kolesterol darah, triglyceride dan LDL-cholesterol.

Jeruk nipis memiliki kandungan metabolit sekunder yang berfungsi untuk menurunkan kadar kolesterol dalam darah antara lain seperti flavonoid, saponin, polifenol, eriocitrin, narigin, tangeretin, minyak atsiri, serta pektin [3]. Senyawa pektin mamempunyai banyak manfaat diantara dapat menurunkan kadar glukosa dan kolesterol [14]. Menurut Indarti (2019) kulit jeruk mengandung senyawa pektin. Pektin dalam kulit jeruk memiliki manfaat untuk menurunkan kadar kolesterol serta kadar gula darah, hal ini dikarenakan pektin mampu mengikat asam empedu. Kandungan flavanoid ekstrak kulit jeruk nipis mampu mengahambat sintesis kolesterol dan sintesis trigliserida tanpa mempengaruhi aktivitas LDL. Hal ini menunjukkan bahwa flavanoid pada ekstrak kulit jeruk nipis berikatan dengan cincin metoksilasi [3].

Suatu senyawa yang terkandung pada tanaman diketahui dapat larut dalam pelarut polar maupun non polar. Partisi adalah salah satu ekstraksi yang berdasarkan sifat kelarutan suatu komponen target serta distribusinya pada dua pelarut yang tingkat kepolarannya berbeda sehingga kedua pelarut tersebut tidak tercampurkan [6]. Partisi digunakan untuk mengetahui adanya senyawa metabolit sekunder dalam pelarut polar dan non polar. Hal ini dikarenakan senyawa metabolit sekunder yang terkandung dalam tanaman itu berbeda-beda kepolarannya. Sehingga diperlukan adanya partisi dengan menggunakan variasi kepolaran pelarut yang berbeda seperti pelarut polar dan pelarut non polar mampu mengefektifkan pada pemisahan senyawa metabolit sekunder dan mendapatkan hasil yang lebih spesifik, dengan demikian maka dapat diketahui efek yang paling tinggi terdapat pada pelarut polar atau non polar [7].

Berdasarkan latar belakang diatas penulis mengambil judul penelitian "Uji aktivitas antikolesterol partisi n-heksana, metanol, dan ekstrak etanol kulit jeruk nipis (Citrus aurantiifolia) secara in vitro".

\section{Metode Penelitian}

\section{Alat dan Bahan}

Alat yang digunakan pada penelitian kali ini yaitu timbangan analitik (Ohaus), loyang, ayakan nomor 40, oven (Memmet), blender (Cosmos $®)$, spektrofotometer UVVIS (Shimadzu), rotary evaporator (Heidolph), mikropipet (Lambda $\Re)$, sentrifugasi, pipet ukur (Pyrex), labu ukur (Pyrex), gelas beker (Pyrex), tabung reaksi (Pyrex), vial, vortex, water bath.

Bahan yang digunakan pada penelitian kali ini yaitu ekstrak kulit jeruk nipis, etanol $96 \%$, n-heksana, metanol, kloroform, $\mathrm{NaOH}, \mathrm{FeCl}_{3}, \mathrm{H}_{2} \mathrm{SO}_{4}$ pekat, $\mathrm{CH}_{3} \mathrm{COOH}$ anhidrat, $\mathrm{HCl}$, serbuk kolesterol murni, pereaksi dragendorff. 


\section{Prosiding Seminar Nasional Kesehatan 2021 Lembaga Penelitian dan Pengabdian Masyarakat Universitas Muhammadiyah Pekajangan Pekalongan}

\section{Prosedur Kerja \\ Determinasi Tanaman}

Tanaman Jeruk Nipis (Citrus aurantiifolia) dalam penelitian diperoleh dari Desa Cibuyur Kecamatan Warungpring Kabupaten Pemalang Provinsi Jawa Tengah dilakukan determinasi untuk spesies tanaman yang digunakan adalah (Citrus aurantiifolia). Determinasi dilakukan di Laboratorium Biologi Fakultas SAINS dan Teknologi Terapan Universitas Ahmad Dahlan.

\section{Pembuatan Simplisia dan Ekstrak}

Jeruk Nipis (Citrus aurantiifolia) dicuci, dikupas, Kulit Jeruk Nipis (Citrus aurantiifolia) dipotong, dikeringkan, diblender dan diayak menggunakan ayakan nomor mesh 40. Serbuk Kulit Jeruk Nipis (Citrus aurantiifolia) dimaserasi menggunakan etanol 96\% (1:5) selama 5 hari. Remaserasi dilakukan selama 2 hari. Filtrat maserasi dan filtrat remaserasi digabungkan kemudian diuapkan menggunakan rotary evaporator pada suhu $40^{\circ} \mathrm{C}$ hingga mendapatkan ekstrak kental kulit jeruk nipis.

\section{Pembuatan Partisi}

Ekstrak kental entanol kulit jeruk nipis ditimbang sebanyak 30 gram ditambahkan larutan n-heksana dan metanol masing-masing sebanyak $100 \mathrm{ml}$ dimasukkan kedalam corong pisah, dikocok dengan kuat. Diamkan selama 24 jam [13]. Fase n-heksana dan fase metanol dipisahkan lalu masing-masing hasil partisi tersebut tampung. Hasil partisi diuapkan menggunakan waterbath untuk mendapatkan ekstrak kental.

\section{Pembuatan Larutan Baku Kolesterol}

Serbuk kolesterol murni ditimbang sebanyak $10 \mathrm{mg}$ dilarutkan kedalam kloroform di labu ukur $10 \mathrm{ml}$ sampai menjadi larutan $1000 \mu \mathrm{g} / \mathrm{ml}$. Larutan baku dibuat seri konsentrasi $100 \mu \mathrm{g} / \mathrm{ml} ; 200 \mu \mathrm{g} / \mathrm{ml} ; 300 \mu \mathrm{g} / \mathrm{ml} ; 400 \mu \mathrm{g} / \mathrm{ml}$; dan $500 \mu \mathrm{g} / \mathrm{ml}$. Setiap konsentrasi dimasukkan dalam labu ukur $10 \mathrm{ml}$ dan dilarutkan dengan kloroform sampai tanda batas.

\section{Penentuan Panjang Gelombang Maksimal}

Pada penentuan panjang gelombang maksimum dalam spektrofotometri UV-Vis dengan melakukan scaning panjang gelombang dari larutan standar kolesterol menggunakan konsentrasi $100 \mu \mathrm{g} / \mathrm{ml} ; 200 \mu \mathrm{g} / \mathrm{ml} ; 300 \mu \mathrm{g} / \mathrm{ml} ; 400 \mu \mathrm{g} / \mathrm{ml}$; dan 500 $\mu \mathrm{g} / \mathrm{ml}$ yang diambil dari larutan stok induk $1000 \mathrm{ppm}$. Larutan kolesterol masingmasing konsentrasi diambil sebanyak $2,0 \mathrm{ml}$ ditambahkan asam asetat anhidrat sebanyak 2,0 $\mathrm{ml}$ dan asam sulfat sebanyak 0,1 ml. Dibiarkan selama 15 menit. Pengukuran dilakukan dengan menggunakan spektrofotometer UV-Vis pada panjang gelombang 400-800 nm.

\section{Kurva Baku Kolesterol}

Larutan baku kolesterol masing-masing seri konsentrasi diambil sebanyak 2,0 ml yang kemudian ditambahkan larutan asam asetat anhidrat 2,0 $\mathrm{ml}$ dan asam sulfat pekat $0,1 \mathrm{ml}$ selanjutnya diinkubasi pada suhu kamar kemudian sampel diukur dimenit ke-15. Diukur absorbansinya dengan menggunakan Spektrofotometri UV-Vis. 


\section{Prosiding Seminar Nasional Kesehatan Lembaga Penelitian dan Pengabdian Masyarakat Universitas Muhammadiyah Pekajangan Pekalongan

\section{Pembuatan Larutan Uji}

Pembuatan larutan uji $1000 \mu \mathrm{g} / \mathrm{ml}$. Larutan uji dari partisi n-heksana, partisi metanol dan ekstrak etanol kulit jeruk nipis masing-masing dibuat seri konsentrasi 150 $\mu \mathrm{g} / \mathrm{ml} ; 300 \mu \mathrm{g} / \mathrm{ml} ; 450 \mu \mathrm{g} / \mathrm{ml} ; 600 \mu \mathrm{g} / \mathrm{ml}$; dan $750 \mu \mathrm{g} / \mathrm{ml}$. Setiap konsentrasi dimasukkan dalam labu ukur $10 \mathrm{ml}$ dan dilarutkan dengan kloroform sampai tanda batas.

\section{Pengukuran Kadar Kolesterol}

Larutan uji partisi n-heksana, partisi metanol dan ekstrak etanol kulit jeruk nipis masing-masing konsentrasi diambil sejumlah 2,0 ml yang ditambahkan larutan kolesterol $400 \mu \mathrm{g} / \mathrm{ml}$ sejumlah 2,0 ml dimasukkan kedalam tabung reaksi, mulut tabung reaksi diberi alumunium foil. Larutan uji masing-masing divortex. Larutan dilakukan setrifugasi dengan menggunakan kecepatan $3000 \mathrm{rpm}$ selama 10 menit. Supernatan diambil sebanyak 3,0 ml dan ditambahkan pula asam asetat sebanyak 2,0 $\mathrm{ml}$ serta asam sulfat pekat sebanyak 0,1 ml, diamkan disuhu kamar selama 15 menit. Serapan larutan dilakukan menggunakan spektrofometer sinar UV dengan panjang gelombang $665,0 \mathrm{~nm}$.

Perhitungan persentase penurunan kadar kolesterol dengan menggunakan persamaan berikut:

$$
A=\frac{C-B}{C} \times 100 \%
$$

Keterangan :

$A=$ Persentase penurunan kolesterol

$\mathrm{B}=$ Absorbansi kolesterol akhir

$\mathrm{C}=$ Absorbansi kolesterol awal

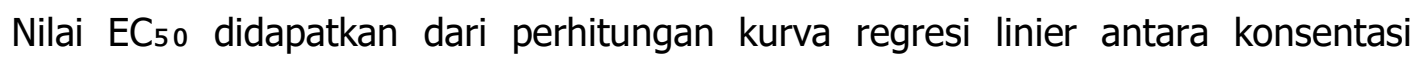
larutan uji dengan persentase kadar penurunan kolesterol, berikut persamaannya :

$$
y=b x+a
$$

Keterangan :

$y=\%$ penurunan kolesterol

$\mathrm{x}=$ konsentrasi sampel

$$
\begin{aligned}
& a=\text { intercept } \\
& b=\text { slope (harga kemiringan kurva) }
\end{aligned}
$$

\section{Analisis Data}

Data yang didapatkan pada hasil penelitian ini adalah kuantitatif. Data kuantitatif diperoleh dari hasil nilai EC50 partisi n-heksana, metanol, dan ekstrak etanol kulit jeruk nipis (Citrus aurantiifolia). 


\section{Hasil dan Pembahasan}

\section{Hasil Penelitian}

Tabel 3.1 Hasil Rendemen Ekstrak Kulit Jeruk Nipis (Citrus aurantiifolia)

\begin{tabular}{ccc}
\hline $\begin{array}{c}\text { Berat Serbuk Simplisia } \\
(\mathrm{gr})\end{array}$ & $\begin{array}{c}\text { Berat Ekstrak } \\
(\mathrm{gr})\end{array}$ & $\begin{array}{c}\text { Rendemen Ekstrak } \\
(\%)\end{array}$ \\
\hline 500 & 62,54 & 12,5 \\
\hline
\end{tabular}

Tabel 3.1 Menunjukkan berat serbuk simplisia Kulit Jeruk Nipis (Citrus aurantiifolia) $500 \mathrm{gr}$, berat ekstrak Kulit Jeruk Nipis (Citrus aurantiifolia) 62,54 gr, dan rendemen ekstrak Kulit Jeruk Nipis (Citrus aurantiifolia) 12,5\%.

Tabel 3.2 Hasil Rendemen Partisi Ekstrak Kulit Jeruk Nipis

\begin{tabular}{cccc}
\hline Pelarut Partisi & Bobot ekstrak (gr) & Bobot Partisi (gr) & Rendemen Partisi (\%) \\
\hline N-Heksana & 30 & 1,55 & 5,1 \\
Metanol & 30 & 22,87 & 76,2 \\
\hline
\end{tabular}

Tabel 3.2 Menunjukkan Bobot ekstrak $30 \mathrm{gr}$, pelarut yang digunakan $100 \mathrm{ml} \mathrm{n}$ heksana dan $100 \mathrm{ml}$ metanol. Bobot partisi n-heksana $1,55 \mathrm{gr}$ dan partisi metanol 22,87 gr. Rendemen partisi n-heksana $5,1 \%$ dan partisi metanol $76,2 \%$.

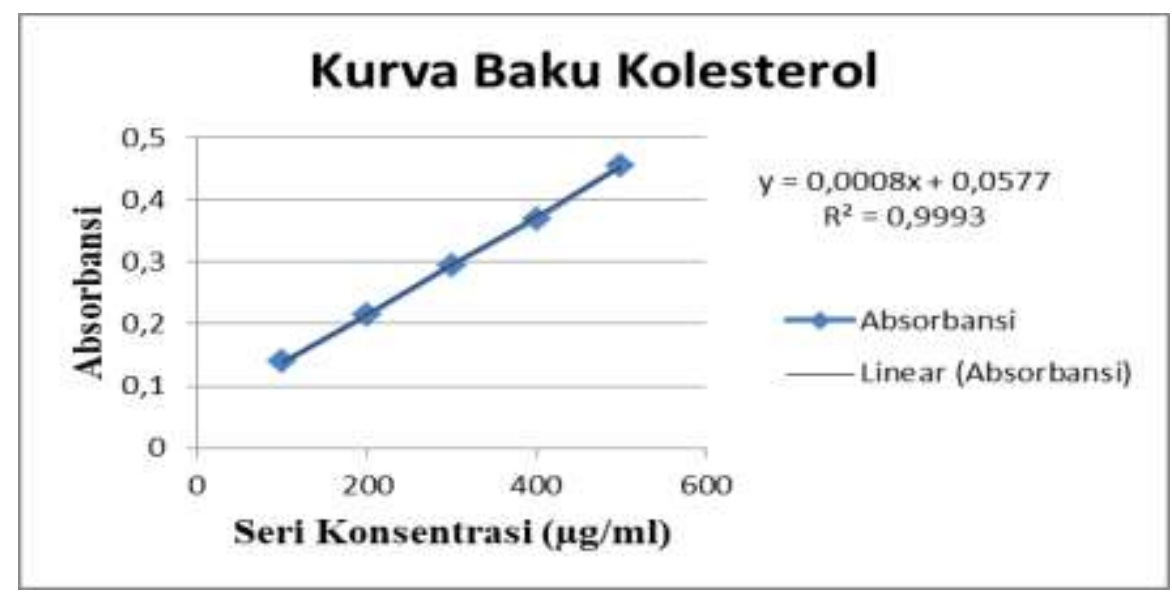

Gambar 3.3 Kurva Baku Kolesterol

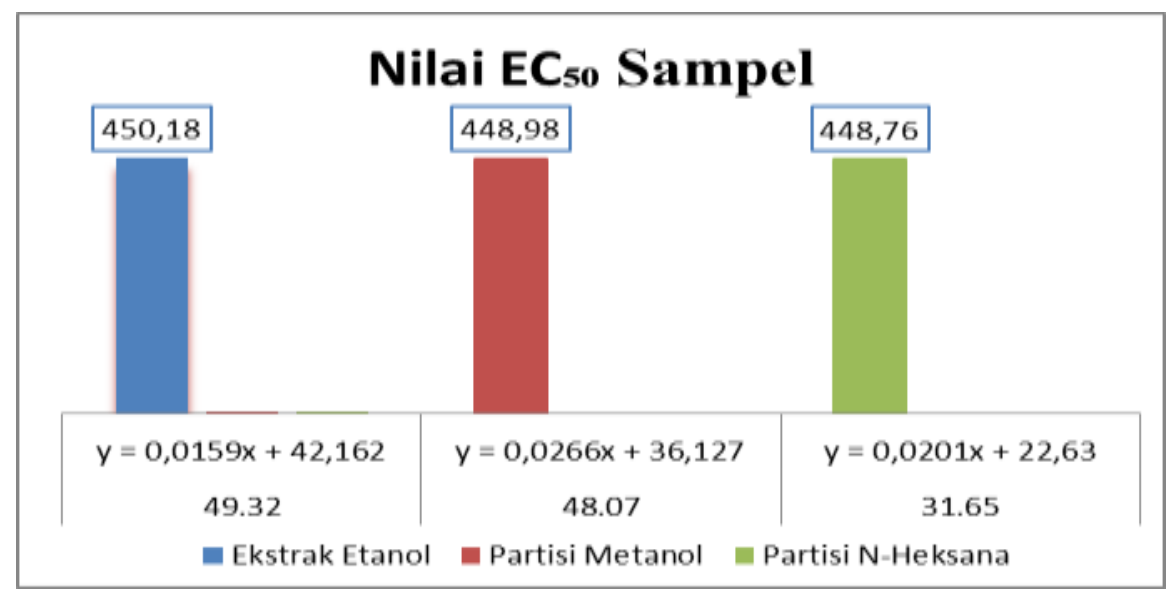

Gambar 3.4 Nilai EC50 pada Partisi N-Heksana, Metanol, dan Ekstrak Etanol Kulit Jeruk Nipis (Citrus aurantiifolia) 


\section{Prosiding Seminar Nasional Kesehatan 2021 Lembaga Penelitian dan Pengabdian Masyarakat Universitas Muhammadiyah Pekajangan Pekalongan}

\section{Pembahasan}

\section{Determinasi}

Determinasi sampel dilakukan di Laboratorium Biologi Fakultas SAINS dan Teknologi Terapan Universitas Ahmad Dahlan pada bulan April 2021. Hasil determinasi sampel dinyatakan pada surat keterangan nomor : 147/Lab.Bio/B/IV/2021 menunjukkan bahwa tanaman sampel adalah jeruk nipis (Citrus aurantifolia).

\section{Penyiapan Simplisia dan Ekstraksi}

Pada bagian kulit jeruk nipis dibuat simplisia kering. Serbuk simplisia Kulit Jeruk Nipis (Citrus aurantiifolia) diayak menggunakan ayakan nomor mesh 40 dengan tujuan untuk mendapatkan keseragaman ukuran serbuk simplisia kulit jeruk nipis (Citrus aurantiifolia). Menimbang sebanyak $500 \mathrm{gr}$ serbuk kulit jeruk nipis dillakukan maserasi dengan menggunakan etanol 96\% (1:5) selama 5 hari dan remaserasi selama 2 hari. Hasil ekstraksi kulit jeruk nipis pada tabel 1 didapatkan ekstrak kental dengan nilai rendemen $12,5 \%$. Rendemen ekstrak adalah senyawa zat aktif yang bisa diambil dari simplisianya yang merupakan perbandingan antara total ekstrak yang didapatkan dengan bobot serbuk simplisia yang digunakan untuk ekstraksi. Rendemen ekstrak menyatakan bahwa adanya senyawa kimia yang terkandung dalam serbuk simplisia kulit jeruk nipis terekstraksi oleh pelarut. Semakin banyak nilai rendemen ekstrak yang dihasilkan maka semakin banyak pula senyawa kimia yang dihasilkan.

\section{Partisi}

Ekstrak kental yang dipartisi sebanyak $30 \mathrm{gr}$ dengan ditambahkan pelarut metanol $100 \mathrm{ml}$ dan n-heksan $100 \mathrm{ml}$ yang dimasukkan ke dalam corong pisah kemudian corong pisah diletakkan pada statip untuk mendiamkan larutan selama 24 jam proses ekstraksi partisi. Hasil partisi ekstrak kulit jeruk nipis pada tabel 2 didapatkan nilai rendemen partisi n-heksan sebanyak $5,1 \%$ dan nilai rendemen partisi metanol sebanyak $76,2 \%$. Hasil yang diperoleh dari proses pemisahan pelarut yang digunakan ekstraksi partisi pada ekstrak etanol kulit jeruk nipis itu lebih banyak pada partisi metanol dibandingkan partisi n-heksana.

Menurut Agniana dkk. (2013) senyawa kimia yang banyak terkandung pada ekstrak kulit jeruk nipis bersifat polar, sehingga pada hasil rendemen partisinya lebih banyak senyawa kimia yang terlarut dalam metanol. Pada proses partisi ada senyawa kimia yang tidak tertarik oleh pelarut $n$-heksana maupun metanol sebanyak 18,7 \%. Hal ini kemungkinan terjadi karena adanya penguapan zat aktif bersama pelarut pada saat proses ekstraksi partisi.

\section{Panjang Gelombang Maksimal}

Panjang gelombang yang didapatkan pada penelitian ini sesuai pada hasil orientasi yaitu $665,0 \mathrm{~nm}$ dengan konsentrasi $400 \mu \mathrm{g} / \mathrm{ml}$ pada larutan baku kolesterol yang direaksikan dengan asam asetat anhidrat sebanyak $2 \mathrm{ml}$ dan asam sulfat pekat sebanyak 0,1 ml. Hal ini disebabkan karena pada puncak tersebut membentuk serapan yang optimal. Menurut penelitian yang dilakukan oleh Ilyas, dkk. (2020) panjang gelombang yang didapatkan yaitu $666,97 \mathrm{~nm}$ dan pada penelitian yang dilakukan oleh Lindawati, dkk. (2020) panjang gelombang yang didapatkan yaitu 668,0 nm. Pada 


\section{Prosiding Seminar Nasional Kesehatan 2021 Lembaga Penelitian dan Pengabdian Masyarakat Universitas Muhammadiyah Pekajangan Pekalongan}

penelitian ini didapatkan panjang gelombang maksimal 665,0 nm, perbedaan panjang gelombang maksimal pada penelitian ini dengan penelitian yang dilakukan Ilyas, dkk. (2020) dan Lindawati, dkk. (2020) dipengaruhi oleh adanya perbedaan pelarut yang digunakan dan adanya perbedaan tipe spektrofotometer yang digunakan.

\section{Kurva Baku}

Nilai koefisien korelasi $(R)$ pada kurva baku kolesterol dipenelitian ini yaitu $\mathrm{R}=$ 0,9995 dengan nilai $a=0,0008$ dan nilai $b=0,0521$ sehingga didapatkan nilai persamaan regresi linier $y=0,0008 x+0,0521$. Nilai koefisien korelasi digunakan untuk menentukan linearitas suatu analisis, dimana nilai a yaitu perpotongan kurva pada sumbu y, sedangkan nilai b yaitu kemiringan kurva.

\section{Mekanisme Kerja Pereaksi Lieberman Burchard}

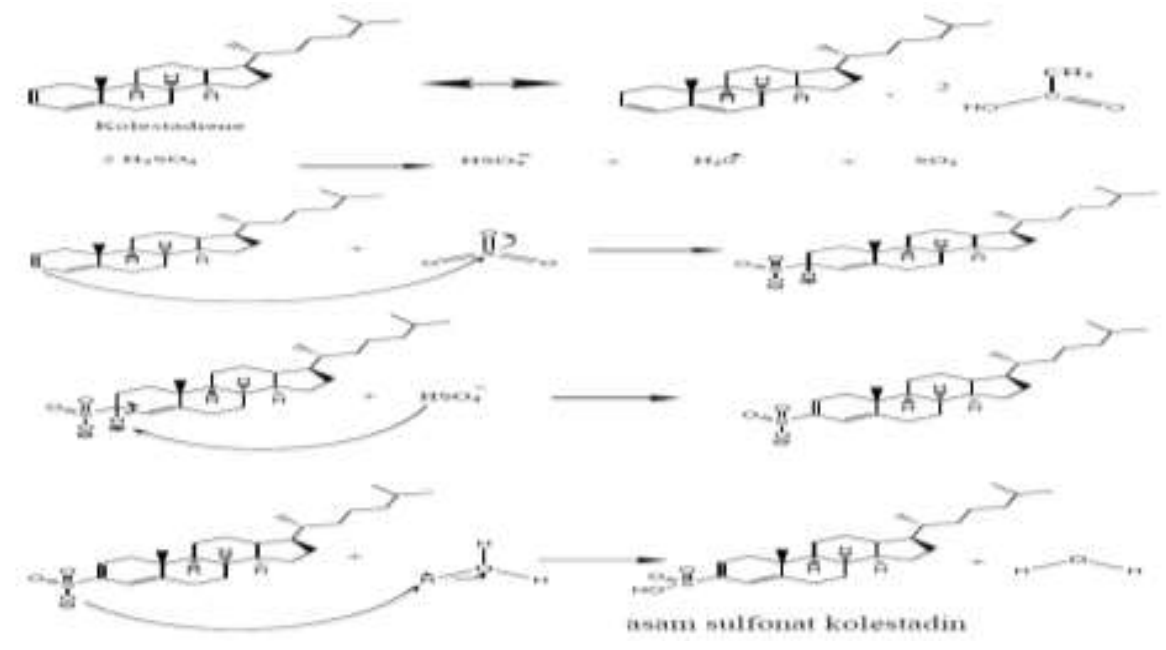

Gambar 3. Mekanisme Reaksi Kolesterol dengan Liberman Burchard [10]

Mekanisme reaksi kolesterol yang berpotensi untuk berikatan dengan flavanoid yaitu adanya asam asetat mengubah struktur kimia kolesterol menjadi kolestadiene. Selanjutnya asam sulfat terurai menjadi $\mathrm{HSO}_{4}, \mathrm{H}_{3} \mathrm{O}$, dan $\mathrm{SO}_{3}$ masing-masing akan berikatan dengan kolestadiene. Reaksi yang akan terbentuk adanya senyawa asam sulfonat kolestadin yang akan berikatan dengan flavanoid, sehingga berperan dalam menurunkan kadar kolesterol dengan menggantikan gugus hidroksil pada asam sulfonat kolestadin dan gugus substituen dari flavanoid. Semakin banyak kolesterol yang berikatan dengan flavanoid dalam sampel maka semakin sedikit kolesterol bebas dan warna yang dihasilkan semakin pudar.

\section{Penurunan Kolesterol pada Ekstrak}

Preparasi dilakukan pembuatan larutan uji $1000 \mu \mathrm{g} / \mathrm{ml}$. Seri konsentrasi larutan uji yaitu $150 \mu \mathrm{g} / \mathrm{ml} ; 300 \mu \mathrm{g} / \mathrm{ml} ; 450 \mu \mathrm{g} / \mathrm{ml} ; 600 \mu \mathrm{g} / \mathrm{ml}$; dan $750 \mu \mathrm{g} / \mathrm{ml}$. Semakin tinggi konsentrasinya, maka larutannya semakin pekat. Pembuatan larutan uji yaitu dengan menimbang partisi metanol, partisi n-heksan, dan ekstrak etanol kulit jeruk nipis masing-masing sampel sebanyak $25 \mathrm{mg}$ yang dilarutkan dalam kloroform sebanyak 25 $\mathrm{ml}$. Kloroform digunakan sebagai pelarut kolesterol dikarenakan menyesuaikan 


\section{Prosiding Seminar Nasional Kesehatan 2021 Lembaga Penelitian dan Pengabdian Masyarakat Universitas Muhammadiyah Pekajangan Pekalongan}

perlakuan pada pembuatan larutan stok baku kolesterol. Pada masing-masing seri konsentrasi dibuat sebanyak $10 \mathrm{ml}$, diambil untuk pengujian masing-masing se banyak 2,0 $\mathrm{ml}$ dimasukkan kedalam tabung sentrifuge yang sudah dilapisi dengan aluminium foil. Tujuan tabung reaksi dan tabung sentrifugasi dilapisi menggunakan aluminim foil yaitu untuk melindungi larutan uji dari cahaya karena jika terkena cahaya maka senyawa yang terkandung akan rusak. Penambahan larutan kolesterol dengan konsentrasi $400 \mu \mathrm{g} / \mathrm{ml}$ sebanyak 2,0 ml. Selanjutnya dilakukan sentrifugasi selama 10 menit dengan kecepatan $3000 \mathrm{rpm}$ yang sebelumnya telah dilakukan vortexing selama 2 menit untuk menghomogenkan antara larutan sampel dengan larutan kolesterol.

Tujuan sentrifugasi merupakan pemisahan cairan dari partikel terhadap densitas layangnya. Tahap selanjutnya yaitu penambahan asam asetat anhidrat sebanyak 2,0 $\mathrm{ml}$ dan asam sulfat pekat sebanyak 0,1 ml. Tujuan dari penambahan asam astetat anhidrat yaitu untuk mengekstraksi dan reaksinya akan membentuk turunan asetil dari steroid [15], sedangkan penambahan asam sulfat dengan tujuan agar terbentuk adanya reaksi warna kompleks larutan yang berwarna hijau. Larutan berwarna hijau disebabkan karena adanya kandungan steroid didalamnya yang termasuk kolesterol. Jenis steroid dalam tanaman adalah fitosterol dengan struktur molekularnya serupa dengan kolesterol [8].

Terbentuk adanya parubahan warna dari warna kuning bening pada larutan kolesterol maka setelah diberi penambahan asam sulfat pekat terbentuk adanya perubahan warna menjadi berwarna hijau pada struktur kimia pada kolesterol terjadi adanya penambahan ikatan yang terkonjugasi. Pada reaksi ini harus terbebas dari kandungan air di dalamnya karena dapat mempengaruhi proses reaksinya yang tidak stabil [10]. Selanjutnya larutan didiamkan selama 15 menit di tempat yang gelap, dikarenakan memiliki sifat fotodegradasi yang tidak stabil jika terkena cahaya [11]. Tujuan didiamkan selama 15 menit, untuk mengoptimakan reaksi dengan maksimal sehingga terbantuk kompleks warna hijau. Senyawa yang terbentuk dilakukan pengukuran pada spektrofotometer UV-Vis dengan panjang gelombang 665,0 nm.

Nilai $\mathrm{EC}_{50}$ (Effective Consentration) adalah nilai yang menggambarkan konsentrasi pada metabolit tertentu yang digunakan dalam menurunkan kadar kolesterol menjadi $50 \%$ dari kadar kolesterol awal total. Nilai $\mathrm{EC}_{50}$ ini diperoleh dari perhitungan persamaan regresi linier $\mathrm{y}=\mathrm{bx}+\mathrm{a}$. Hubungan konsentrasi larutan uji sampel (nilai $\mathrm{x}$ ) dengan rata-rata dari persentase penurunan kadar kolesterol (nilai y)

Berdasarkan hasil yang didapatkan pada gambar 4.5 menunjukkan nilai EC50 pada sampel ekstrak etanol yaitu 450,18 $\mu \mathrm{g} / \mathrm{ml}$. Nilai EC50 pada sampel partisi metanol yaitu $448,98 \mu \mathrm{g} / \mathrm{ml}$. Nilai EC50 pada sampel $\mathrm{N}$-Heksana yaitu $448,78 \mu \mathrm{g} / \mathrm{ml}$. Nilai EC50 yang terbaik merupakan pada sampel ekstrak etanol sebesar $450,18 \mu \mathrm{g} / \mathrm{ml}$.

\section{Kesimpulan}

Berdasarkan hasil penelitian, maka dapat disimpulkan bahwa partisi n-heksana, partisi metanol, dan ekstrak etanol kulit jeruk nipis (Citrus aurantiifolia) mempunyai aktivitas penurunan kolesterol dengan menunjukkan nilai $\mathrm{EC}_{50}$ partisi n-heksana sebanyak 448,76 $\mathrm{\mu g} / \mathrm{ml}$; partisi metanol sebanyak 448,98 $\mathrm{\mu g} / \mathrm{ml}$ dan ekstrak etanol sebanyak $450,18 \mu \mathrm{g} / \mathrm{ml}$. 


\section{Prosiding Seminar Nasional Kesehatan $\mathbf{2 0 2 1}$ Lembaga Penelitian dan Pengabdian Masyarakat Universitas Muhammadiyah Pekajangan Pekalongan}

\section{Referensi}

[1] E. Mulyani, "Studi In Vitro: Efek Anti Kolesterol Ekstrak Daun Rambusa (Passiflora foetida L)," J. Surya Med., vol. 4, no. 2, pp. 60-65, 2019, doi: 10.33084/jsm.v4i2.606.

[2] Y. Elon and J. Polancos, "Manfaat Jeruk Nipis (Citrus Aurantifolia) dan Olahraga Untuk Menurunkan Kolesterol Total Klien Dewasa Effect of Lime (Citrus Aurantifolia) and Excersise To Reduce Total Cholesterol of Adults Client," J. Sk. Keperawatan, vol. 1, no. 2, pp. 148-155, 2015.

[3] N. Agrawal and S. A. Smith, "Optimal inventory management for a retail chain with diverse store demands," Eur. J. Oper. Res., 2013, doi: 10.1016/j.ejor.2012.10.006.

[4] T. W. Indarti, "Uji Aktivitas Antikolesterol Ekstrak Etanol Kulit Jeruk Manis (Citrus sinensis L.) pada Mencit (Mus musculus) Jantan," Skripsi STIK Siti Khadijah Palembang, p. 43, 2019.

[5] A. M. Agniana, R. Maftuchah, and S. K. Sunarko, "The Effect of Lime Peel Extract (Citrus aurantifolia) to Total Blood Cholesterol Levels of Mice (Mus musculus) That Given The High Cholesterol Diet," Folia Medica Indones., vol. 49, no. 4, pp. 208-215, 2013, [Online]. Available: http://eds.b.ebscohost.com/eds/detail/detail?sid=b9046028-0670-4424-b359d2513dfd80ba@sessionmgr120\&vid=0\&hid=121\&bdata=Jmxhbmc9ZXMmc2I0ZT $1 / Z H M t b G I 2 Z Q==\# A N=108838640 \& d b=a 9 h$.

[6] E. Hanani, Analisis Fitokimia. Jakarta, 2015.

[7] E. R. I. Setyaningrum, "Uji Toksisitas Partisi N-Heksan dan Partisi Metanol dari Herba Benalu Teh (Loranthus sp) sebagai Skrinning Awal Antikanker dengan Metode BSLT (Brine Shrimp Lethality Test)," 2019.

[8] A. N. Ilyas, R. Rahmawati, and H. Widiastuti, "Uji Aktivitas Antikolesterol Ekstrak Etanol Daun Gedi (Abelmoschus Manihot L. Medik) Secara In Vitro," Wind. Heal. J. Kesehat., vol. 3, no. 1, pp. 57-64, 2020, doi: 10.33368/woh.v0i0.216.

[9] N. Y. Lindawati and D. W. Ningsih, "Aktivitas Antikolesterol Ekstrak Etanol Buah Kiwi Hijau (Actinidia deliciosa)," J. Ilm. Manuntung, vol. 6, no. 2, p. 183, 2020, doi: $10.51352 /$ jim.v6i2.344.

[10] D. I. Anggraini and E. W. Kusuma, "Uji Potensi Fraksi Etil Asetat Kulit Buah Apel Hijau (Pyrus malus L.) Terhadap Penurunan Kadar Kolesterol Secara In Vitro," J. Ilm. Cendekia Eksakta, pp. 7-15, 2017.

[11] D. I. Anggraini dan L. F. Nabillah, "Activity Test of Suji Leaf Extract (Dracaena angustifolia Roxb.) on in vitro cholesterol lowering," J. Kim. Sains dan Apl., vol. 21, no. 2, pp. 54-58, 2018, doi: 10.14710/jksa.21.2.54-58.

[12] Prasetyo and E. Inoriah, Pengelolaan Budidaya Tanaman Obat-Obatan (Bahan Simplisia). Bengkulu: Badan Penerbitan Fakultas Pertanian UNIB, 2013.

[13] L. M. Nurulita, Slamet, dan N. A. Aktifah, "Uji Perbandingan Aktivitas Antioksidan Partisi N-Heksan, Metanol, dan Ekstrak Etanol Biji Mentimun (Cucumis sativus L.) 


\section{Prosiding Seminar Nasional Kesehatan Lembaga Penelitian dan Pengabdian Masyarakat Universitas Muhammadiyah Pekajangan Pekalongan

dengan Metode Frap (Ferric Reducing Antioxidant Power)," Univ. Muhammadiyah Pekajangan Pekalongan, pp. 1-9, 2019.

[14] P. Dhaneswari, C. G. Sula, Z. Ulima, and P. Andriana, "Pemanfaatan Pektin yang Diisolasi dari Kulit dan Buah Salak (Salacca Edulis Reinw) dalam Uji In Vivo Penurunan Kadar Kolesterol dan Glukosa Darah pada Tikus Jantan Galur Wistar," Khazanah, vol. 7, no. 2, pp. 39-60, 2015, doi: 10.20885/khazanah.vol7.iss2.art4.

[15] Muhammad Saiful Amin, "Efek Antikolesterol dari Ekstrak Metanol Buah Parijoto (Medinilla speciosa Blume) Terhadap Kolesterol Total," Skripsi UIN Syarif Hidayatullah Jakarta, 2015. 